\title{
Assuring Quality in Promoting Generic Skills in the Higher College of Technology (HCT), Muscat: Challenges \& Realities
}

\author{
Holi Ibrahim Holi Ali ${ }^{1}$ \\ ${ }^{1}$ School of Education \& Professional Development, University of Huddersfield, UK \\ Correspondence: Holi Ibrahim Holi Ali, PhD Student of Applied Linguistics \& TESOL, School of Education \& \\ Professional Development, University of Huddersfield, UK. Tel: 96-892-295-223. E-mail: howlli2@yahoo.com
}

Received: July 30, 2012 Accepted: August 28, 2012 Online Published: September 12, 2012

doi:10.5539/elt.v5n11p45 URL: http://dx.doi.org/10.5539/elt.v5n11p45

\begin{abstract}
This paper explores EFL teachers' perceptions in relation to the pedagogical and conceptual challenges that they face in promoting generic skills in the Higher College of Technology (HCT), Muscat, in the context of post foundation level provision. A questionnaire was administered to $17 \mathrm{EFL}$ teachers at $\mathrm{HCT}$, at post foundation levels to investigate their views and beliefs about challenges in assuring quality in promoting generic skills. The study reveals that assessment and teaching provide the most obvious pedagogical challenges; whereas teachers' understanding and interpretations of generic skills are the most common conceptual challenges. Recommendations on how generic skills could be enhanced and promoted and how these challenges can be overcome are presented.
\end{abstract}

Keywords: assuring quality, promoting generic skills, pedagogical challenges, conceptual challenges, EFL teachers in Oman

\section{Introduction}

Currently, the majority of higher education (HE) institutions in Oman emphasizes in their missions and visions that teaching and acquisition of generic skills is amongst their prime goals for their graduates. However, teaching these skills and assuring its quality is not an easy task given several challenges. The study attempts to shed light on teachers' perceptions about generic skills and pedagogical challenges such as teaching and assessment. It considers conceptual challenges which are related to teachers' understanding and interpretations of these skills and their effects on assuring quality in the promotion of these skills to the post foundation students in the Higher College of Technology (HCT) in Muscat, Oman. It identifies some pedagogical suggestions for overcoming these challenges. Most of the generic skills are clearly stated in the missions and visions for HCT and for its English Language Centre (ELC), and the Approach, Deployment, Results and Improvement (ADRI) cycle is used in the operational plan to implement them, but still there are many challenges that could affect teaching and assessment qualities. This problem was formulated on the basis of practical experience in the field; teaching and assessing generic skills present great challenges for teachers who teach EAP at post foundation level. Theoretically, teaching and learning discipline knowledge is believed to be easier than teaching and acquiring generic skills. Bath et al. (2004, cited in McLean 2010) claimed that the learning of discipline knowledge is emphasized over the development of the general intellectual and social skills and capabilities (transferable or generic). However, these generic skills or attributes are very important for graduates. The findings of this study are intended to assist in the promotion of generic skills in higher education in general, and at HCT in particular.

\section{An Overview on Generic Skills}

\subsection{Defining Generic Skills}

Generic skills have been defined by many scholars but the most frequently cited ones are such as McLean's (2010) who identified generic skills or (graduate attributes or capabilities) to be such as team work, communication, problem-solving, analytical and critical thinking and leadership as the core capabilities of any graduate irrespective of the field of study. There are many terms that have been used to describe these skills including core capabilities, key skills, transferable skills, graduates capabilities, soft skills, essential skills, and even personal and professional capabilities. In Australia, these skills are referred to as generic graduate attributes (GGAs). According to the Higher Education Council (HEC, 1990, cited in Mclean 2010, p. 12) transferable attributes are the skills, knowledge and abilities of university graduates beyond disciplinary context knowledge, 
which are applicable in a range of contexts and are required as a result of completing any undergraduate degree. Moreover, Mayer (1992, cited in Sanguinetti 2004, p. 1) described them as "core skills" or "key competencies" which are seen as skills that a graduate needs in order to function effectively in his or her potential career.

Further, Bowden et al (2000) described these generic skills as the qualities, skills, and understandings a university community agrees that its students should develop during their time with the institution. These attributes include, but go beyond the disciplinary expertise or technical knowledge that has traditionally formed the core of most university courses. Archer \& Davison (2008, cited in Mclean, 2010), classified generic skills into "soft skills" such as communication, team work and social skills and "hard skills" such as numeracy, literacy and IT skills." Parsons (2009, cited in Ntombela, 2010) described "soft skills" as attributes that enhance an individual's job performance and career prospects. It is quite evident that these definitions have many things in common.

Graduate attributes are important for universities, colleges and indeed any tertiary institution. Bowden et al (2000) argued that there are three reasons or principal arguments why universities or tertiary institutions should consider generic skills and give them priority in the programmes they offer. Firstly, to provide educated citizens who are capable of functioning as "agents of social good" and function effectively in the community? Therefore, graduates require more than disciplinary or technical knowledge. Secondly, the universities and tertiary institutions need to prepare their graduates for unknown future; therefore, generic skills are important for these unfamiliar situations. Finally, the labour market and employment demand more than disciplinary expertise which is only one of the large set of abilities and skills which determine whether an individual will be successful in his/ her job or not. Further, Bowden \& Marton (1998, cited in HART et al, ND) argued that the curriculum for any university needs to be developed around the idea that students are being prepared for unknown futures. The traditional knowledge which prepared a graduate in the past is no longer applicable to the demands of both today's and the future job market. Today's graduates need to be confident about tackling new challenges in an ever-changing and dynamic workplace context which requires higher-order thinking skills.

Star and Hammer (2008) asserted that “... teaching students' graduate skills can facilitate their mastery of disciplinary knowledge, and develop their sense of judgment..." (2008, 238). Further, Imel (1999, cited in Ong, $\mathrm{ND}$ ) suggested that in the past two decades, skills needed to perform successfully in the workplace have changed significantly due to the new labour market's demands and needs and they are crucially as important as technical skills. HEC (1990) added that generic skills "should represent the central achievements of higher education as a process so as to enable graduates to be receptive to innovation, adaptable to change, and more able to manage more flexible culture" Nguyen et al (1997, p. 3). Ntombela (2010, pp. 598-599) claimed that: "soft skills are increasingly becoming a determining factor of success in the employment sector; it behooves higher institutions of learning to prepare students for the job market with soft skills; i.e. bringing soft skills into a classroom environment."

\subsection{Challenges in Promoting Generic Skills}

There are many challenges which encounter both language and core subject teachers in succeeding in teaching, assessing and assuring the quality of generic skills. Varsavsky (2010) reported the following challenges which were encountered when running a program for promoting generic skills in the Faculty of Science of Monash University in Australia. The first challenge was teaching methodology, where a new teaching method had to be used instead of lecturing to foster these skills. Secondly, the tutors' roles or duties had increased and they felt that their immediate role was to teach core subjects not these skills. Sanguinetti (2004) claimed that the challenge lies in pedagogy and assessment, and that it is difficult to assess generic skills performatively as they usually involve learning through trial and error which incorporates risk and experimentation which is not always possible to replicate in classrooms. Ginns, Prasser, and Barrie, (2007; Kuh, 2004; and Webster, Chan, Prasser, \&Walkins, 2009, cited in Chan, 2010) asserted that the most common method for evaluating generic skills in under graduate education is self-report surveys. The survey items focused on students' perceptions of their development in problem-solving, decision making, analytical skills, communication, ethical development, vocational preparation within the institution environment. However, even if generic skills are proven to be effectively developed, the applicability of these skills outside the educational context is stills in question. Star \& Hammer (2008) pointed out that the "graduate skills assessment" test devised by the Australian Council of Educational Research (ACER), exemplifies the pitfalls of other methods adopted by assessors in the field. However, it was criticized by Beckett, (2004), Chanock et al., (2004, cited in Star and Hammer, 2008, p. 240) as "poorly targeted, de-contextualized and cannot measure the kind of skills employers are looking for in university graduate."

Moreover, generic skills cannot be developed in isolation, but must be engendered in a social context, through communities of practice and real life or authentic environments. Also, generic skills are not assessable unless 
carried out as discrete entities with the person. Bowden et al (2000) pointed out that the development of generic skills has little meaning unless embedded within the context of the discipline. Therefore, it is important for generic skills to be contextualized within all disciplines. Janes (2009a, cited in Mclean, 2010) stated that teachers have different conceptions, understanding and interpretation of these skills; and how these capabilities should be developed in the learners is considered to be a challenge. This is a lack of understanding how to teach them, and they are often too de-disciplined and de-contextualized- this will impede an effective implementation. It is evident that the most common challenges encountered in promoting generic skills are "pedagogical", and "conceptual". Further, Star and Hammer (2008) added that there were many challenges in implementing and teaching generic or graduate skills such as inconsistencies in interpretation, and disagreement over who is responsible for skill-based teaching and developing these skills. Further, man tutors hold strong preferences for teaching content over process.

\section{Research Questions}

1. How are generic skills perceived and understood by EFL teachers?

2. What are the challenges encountered by teachers in promoting generic skills?

3 . What are the possible strategies for promoting these skills and assuring its quality?

\section{Methods}

A questionnaire was administered to 17 teachers at HCT, Muscat, who were chosen on the basis of having the experience of teaching post foundation programmes. The questionnaire contained 9 statements which were divided roughly into pedagogical and conceptual challenges. It followed Linkert-3 point scale. The participants were EFL teachers from different nationalities: India, Oman, Pakistan, Philippine, Sudan, Iraq, Tunisia, etc. They have been teaching in Oman for several years. These data were analysed quantitatively and frequencies and percentages were used to analyse statistically. The results were tabulated and presented against the study questions.

\section{Result}

These results are subject to several limitations. The study does not investigate the effects of other challenges that could influence quality assurance in promoting generic skills such as the quality of instruction, input from core subjects, students' previous knowledge, etc. Rather than a general survey for post foundation teachers' and students' perceptions this study focused only on pedagogical and conceptual challenges and their effects in assuring the quality of generic skills. Moreover, the number of the participants was limited to 17 EFL teachers who were teaching at post foundations which may not constitute a representative sample. Moreover, it is acknowledged that the external validity of this study may be limited.

Table 1. Analysis of Teachers' Questionnaire

\begin{tabular}{|c|c|c|c|c|c|c|c|}
\hline \multirow[t]{2}{*}{ No } & \multirow[t]{2}{*}{ Statements } & \multicolumn{2}{|c|}{ Agree } & \multicolumn{2}{|c|}{ Undecided } & \multicolumn{2}{|c|}{ Disagree } \\
\hline & & Freq & $\%$ & Freq & $\%$ & Freq & $\%$ \\
\hline 1. & $\begin{array}{l}\text { Generic skills are important and should be taught as a discrete subject } \\
\text { for students. }\end{array}$ & 12 & $71 \%$ & 2 & $12 \%$ & 3 & $18 \%$ \\
\hline 2. & $\begin{array}{l}\text { I know what generic skills are and how to promote them in my } \\
\text { teaching context. }\end{array}$ & 11 & $65 \%$ & 4 & $24 \%$ & 8 & $47 \%$ \\
\hline 3. & Generic skills can easily be taught and assessed. & 2 & $12 \%$ & 7 & $41 \%$ & 8 & $47 \%$ \\
\hline 4. & $\begin{array}{l}\text { I believe that it is English language teachers' responsibility to develop } \\
\text { students' communication, teamwork, critical thinking and problem } \\
\text { solving skills rather than core subject teachers. }\end{array}$ & 7 & $41 \%$ & 4 & $24 \%$ & 6 & $35 \%$ \\
\hline 5. & $\begin{array}{l}\text { Developing and promoting and generic skills and assuring their quality } \\
\text { should always be a shared responsibility between English language } \\
\text { and core subjects' teachers. }\end{array}$ & 12 & $71 \%$ & 4 & $24 \%$ & 1 & $6 \%$ \\
\hline 6. & $\begin{array}{l}\text { I think teaching and assessing critical thinking and problems solving, } \\
\text { communication and team -working skills are challenges in English } \\
\text { language classroom. }\end{array}$ & 12 & $71 \%$ & 5 & $29 \%$ & 0 & 0 \\
\hline 7. & $\begin{array}{l}\text { Assuring quality in teaching and assessing communication and critical } \\
\text { thinking and problem solving, and team-working skills is difficult for } \\
\text { me. }\end{array}$ & 5 & $29 \%$ & 6 & $35 \%$ & 3 & $35 \%$ \\
\hline 8. & $\begin{array}{l}\text { Assessing generic skills out of the context of disciplinary knowledge is } \\
\text { difficult for me. }\end{array}$ & 6 & $35 \%$ & 8 & $47 \%$ & 3 & $18 \%$ \\
\hline 9. & $\begin{array}{l}\text { I think assessing generic skills out of a real work environment or } \\
\text { authentic situation is a real challenge. }\end{array}$ & 12 & $71 \%$ & 3 & $18 \%$ & 2 & $12 \%$ \\
\hline
\end{tabular}

In response to question 1, whether generic is important and should be taught as a discrete subject, 12 teachers 
(71\%) agreed, 2 teachers (12\%) said they were uncertain, and 3 teachers $(18 \%)$ disagreed and they believed that they are not important to be taught. It is very clear that the vast majority of the teachers believed that generic skills are important to be taught as a discrete subject. As for question 2, 11 teachers $(65 \%)$ reported that they know what generic skills are and how to promote them, 4 teachers (24\%) were uncertain and only 3 teachers $(18 \%)$ disagreed. Concerning question 3, whether generic skills can easily be taught and assessed, 2 teachers (12\%) agreed, 7 teachers $(41 \%)$ were uncertain, and 8 teachers $(47 \%)$ disagreed. Thus, it is quite evident that a considerable number of teachers claimed that generic skills cannot be easily taught and assessed.

As for question 4, 7 teachers (41\%) believed that it is the English language teachers' responsibility to develop students' generic skills not the core subject teachers, 4 teachers (24\%) were uncertain and only 6 teachers (35\%) disagreed. Regarding question 5, 12 teachers $(71 \%)$ agreed that developing generic skills is a shared responsibility between English language teachers and core subject teachers, 4 teachers $(24 \%)$ were uncertain, only 1 teacher $(6 \%)$ disagreed. It is quite clear that the majority of teachers believed that promoting these skills is a shared responsibility.

Concerning questions 6,12 teachers (71) agreed that teaching and assessing critical thinking skills such as critical thinking, communication, problem-solving and team-working skills are a real challenge in the English language classroom, 5 teachers (29\%) were uncertain and 6 teachers (35\%) disagreed. As for question 7, whether assuring quality in teaching and assessing critical thinking, communication, problem-solving and team-working skills is difficult, 5 teachers $(29 \%)$ agreed, 6 teachers $(35 \%)$ were uncertain, and 6 teachers $(35 \%)$ disagreed. Regarding question 8 , whether generic skills can be assessed out of the context of disciplinary knowledge is difficult or not, 6 teachers (35\%) agreed, 8 teachers (47) were uncertain, and only 3 teachers (18\%) disagreed. In response to question 9 , whether assessing generic skills out of a real work environment is a real challenge, 12 teachers $(71 \%)$ agreed, 3 teachers $(18 \%)$ were uncertain, and only 2 teachers $(12 \%)$ disagreed. Therefore, it is quite clear that the great majority of teachers believed that assessing these skills out of their real context would be difficult and unreliable.

\section{Conclusion and Recommendations}

The importance of generic skills is evidenced by the drive for tertiary institutions to incorporate team-working skills, critical thinking, etc. into their visions and missions and in their study programmes. This drive is based in the recognition that generic skills undoubtedly facilitate graduate employability. From this survey analysis, it can be concluded that teachers appreciated generic skills but they faced many challenges in promoting them. However, the challenges investigated have shown that pedagogical and conceptual challenges are the most common. The study results revealed that most of the post foundation teachers believed that there are conceptual and pedagogical challenges in promoting skills in their teaching context.

This study findings and results must be treated with caution, because these results are subject to several limitations. In light of the findings, the following recommendations are made:

- Assuring quality in teaching and assessing generic skills out of the context of the disciplinary knowledge is difficult and therefore, there should be collaboration between core subject teachers and language teachers to promote and develop these skills.

- Both core subjects and English language teachers should be trained to teach, assess and promote these skills effectively and should be well-equipped to overcome the pedagogical challenges.

- Teaching generic skills and assuring their quality are best contextualized.

- Emphasis on the promotion of generic skills should be concentrated on post foundation and core subjects courses to help the students to acquire them and use them purposefully.

\section{References}

Bowden et al. (2000). Generic Capacities of ATN University Graduates. Retrieved from http://www.clt-uts.edu.au/ATN; http://grad.Cap.project.index

Chan, W, S. C. (2010). Students' Understanding of Generic Skills Development in a University in Hong Kong. Retrieved from http://www.sciencedirect.com/science/article/pii/S1877042810008165

Hammer, S., \& Star, C. (2008). Teaching Generic Skills: Eroding the Higher Purpose of Universities, or an Opportunity for renewal? Oxford Review of Education, 34(2), 237-251. http://www.tandfonline.com/doi/abs/10.1080/03054980701672232

McLean, M. (2010). Citizen for an Unknown Future: Developing Generic Skills and Abilities. Paper presented at Academic Research Symposium: Higher Education in the Gulf: research insights in learning and teaching, 
Zayed University, Dubai, $18^{\text {th }}$ March 2010.

Nguyen, D, Q. (1998). The Essential Skills and Attributes of an Engineer: A comparative Study of Academics, Industry Personnel and Engineering Students. Global Journal of Engineering Education, 2(1).

Ntombella, B. (2010). Acquisition of Soft Skills. The Proceeding of the Asian Conference on Arts and Humanities 2010, Japan.

Ong, E. (ND). Generic Skills Assessment in Malaysian Tertiary Institution: A survey of Stakeholders' Perceptions. JIRSEA (ISSN: 1675-6061), 1(2).

Sanguinetti, J. (2004). Generic Skills for Employability: Educational Colonization or Educational Opportunity?

Varsavsky, C. (2001). Developing Generic Skills of First-Year Science Students. Invited paper given at UniServe Science FYE Discussion Forum, April 19, 2001.

\section{Appendix A}

\section{Dear Colleagues:}

This questionnaire is meant to explore your views and perceptions about challenges in teaching generic skills in our teaching context. I would be grateful if you could answer all the questions objectively and honestly. You may be assured that your responses will be regarded as confidential information and will be used only for research purposes.
Agree $=3$
Undecided $=2$
Disagree $=1$

Table 2. Teachers' Questionnaire

\begin{tabular}{|c|c|c|c|c|}
\hline No & Statements & Agree & Undecided & Disagree \\
\hline 1. & $\begin{array}{l}\text { Generic skills are important and should be taught as a discrete } \\
\text { subject for students. }\end{array}$ & & & \\
\hline 2. & $\begin{array}{l}\text { I know what generic skills are and how to promote them in my } \\
\text { teaching context. }\end{array}$ & & & \\
\hline 3. & Generic skills can easily be taught and assessed. & & & \\
\hline 4. & $\begin{array}{l}\text { I believe that it is English language teachers' responsibility to } \\
\text { develop students' communication, teamwork, critical thinking and } \\
\text { problem solving skills rather than core subject teachers. }\end{array}$ & & & \\
\hline 5. & $\begin{array}{l}\text { Developing and promoting and generic skills and assuring their } \\
\text { quality should always be a shared responsibility between English } \\
\text { language and core subjects' teachers. }\end{array}$ & & & \\
\hline 6. & $\begin{array}{l}\text { I think teaching and assessing critical thinking and problems solving, } \\
\text { communication and team-working skills are challenges in English } \\
\text { language classroom. }\end{array}$ & & & \\
\hline 7. & $\begin{array}{l}\text { Assuring quality in teaching and assessing communication and } \\
\text { critical thinking and problem solving, and team-working skills is } \\
\text { difficult for me. }\end{array}$ & & & \\
\hline 8. & $\begin{array}{l}\text { Assessing generic skills out of the context of disciplinary knowledge } \\
\text { is difficult for me. }\end{array}$ & & & \\
\hline 9. & $\begin{array}{l}\text { I think assessing generic skills out of a real work environment or } \\
\text { authentic situation is a real challenge. }\end{array}$ & & & \\
\hline
\end{tabular}




\section{Appendix B}

Table 3. Responses Frequency Count

\begin{tabular}{llll}
\hline Question & Responses Frequency & & $\mathbf{1}$ \\
\cline { 2 - 4 } & $\mathbf{3}$ & $\mathbf{2}$ & 3 \\
\hline 1 & 12 & 2 & 8 \\
\hline 2 & 11 & 4 & 8 \\
\hline 3 & 2 & 7 & 6 \\
\hline 4 & 7 & 4 & 1 \\
\hline 5 & 12 & 5 & 0 \\
\hline 6 & 12 & 5 & 3 \\
\hline 7 & 5 & 6 & 3 \\
\hline 9 & 6 & 8 & 2 \\
\hline
\end{tabular}

\section{Appendix C}

Table 4. Percentages

\begin{tabular}{llll}
\hline Question & \multicolumn{2}{l}{ Responses Percentages } & $\mathbf{2}$ \\
\cline { 2 - 4 } & $\mathbf{3}$ & 12 & $\mathbf{1}$ \\
\hline 1 & 71 & 24 & 18 \\
\hline 2 & 65 & 41 & 47 \\
\hline 3 & 12 & 24 & 47 \\
\hline 4 & 41 & 24 & 35 \\
\hline 5 & 71 & 29 & 6 \\
\hline 6 & 71 & 35 & 0 \\
\hline 7 & 29 & 47 & 35 \\
\hline 8 & 35 & 18 & 18 \\
\hline 9 & 71 & & 12 \\
\hline
\end{tabular}

